\title{
On the 'Specialness' of the Criminal Law
}

\author{
Matt Matravers ${ }^{1}$ (D)
}

Accepted: 15 September 2021 / Published online: 24 September 2021

(c) The Author(s) 2021

Keywords Criminal Law Theory $\cdot$ Criminal Law Exceptionalism $\cdot$ Punishment

This comment begins with some thoughts on the question of 'criminal law's exceptionalism' and on what (seems to) motivate the question. It then moves on to a brief survey of some candidate criteria for the distinctive nature of the criminal law. ${ }^{1}$ The argument is that there is a defensible account of criminal law and punishment as distinctively valuable, but that this account does not have to be 'apolitical' and, perhaps even more importantly, it does not provide reasons for criminal law and punishment to be excluded from evaluation as instruments of public policy that may, or may not, be all things considered justified.

\section{Why Worry?}

Alice Ristroph, who has pioneered arguments around 'exceptionalism', distinguishes between 'exceptionalism' as a feature of theorising about the criminal law and 'exceptionality' as (an alleged) feature of the practice of the criminal law. ${ }^{2}$ Ristroph's work has resonated with others-as evidenced from the current issue-in the main because it seems to capture various concerns that are both historical and contemporary (that is, concerns that include, but also go beyond, those identified by Ristroph herself). I suspect that these concerns are more 'a community stew where everyone throws something different into the pot' ${ }^{3}$ than a single coherent position, but that nevertheless certain common themes can be identified.

\footnotetext{
${ }^{1}$ For the reasons given in Antony Duff and Sandra Marshall's contribution (that something can be distinctive but not be exceptional in being so), my main concern is with the claim that there is (or is not) something 'distinctive' in the criminal law. However, I have retained the language of 'exceptionalism', and even 'specialness', in places either to reflect the literature under discussion or where it usefully illuminates a particular worry.

${ }^{2}$ Alice Ristroph, "An Intellectual History of Mass Incarceration", Boston College Law Review 60 (2019): 1949.

${ }^{3}$ William A. Galston, "Realism in political theory", European Journal of Political Theory 9(4) (2010): 386. The debate between so-called high liberals and realists in political philosophy, which is neatly captured by Galston, seems to me to have a great deal to teach legal theorists (indeed, the current debate amongst legal theorists feels almost like a re-run of the one in political philosophy).
}

Matt Matravers

matt.matravers@york.ac.uk

1 University of York, York, UK 


\subsection{The Problem with Theory}

It is not possible to survey all the allegations made against 'liberal criminal law theory', but some of the worries can be captured fairly succinctly. Such theory, it is said, is ahistorical, insensitive to other disciplines, and (most importantly) apolitical. It is, to borrow a phrase from the 'realist' debate in political philosophy, mere 'applied moral philosophy'. ${ }^{4}$ This, it is claimed, is inapt in ignoring criminal law as a 'political institution'. 5 Moreover, such theorising — which places the criminal law in the realm of the 'vindication of private right', 6 is dangerous because it provides a basis on which to exempt criminal law from the usual tests of both public justification and public policy. It is this idea, I think, that links the critics' theoretical and practical arguments. By making criminal law about individual rights and justice, exceptionalism in theory drives the thought that in practice "nothing else [but the criminal law and punishment] will do'. ${ }^{7}$ For example, that 'criminal law provides a distinctive form of condemnation for which there is simply no substitute'. 8

A different form of the argument goes the other way (from practice to theory rather than vice-versa). That is, the claim is that (some) theorists are too impressed by the alleged exceptionality of criminal law and allow this to shape their exceptionalist theories. More prosaically, the criticism is that certain theorists look at criminal law and punishment, erroneously find in it various special features (for example, its imposition of hard treatment) and then take it as their task to provide an account of criminal law and punishment that explains and justifies these (non-existent) special features. What are these features, do they exist, and do they stand up to scrutiny as 'special'?

\section{Candidate 'Special' Features}

Following Ristroph, I shall consider the burdens the criminal law imposes, the content it covers, and aspects of its processes or operations. ${ }^{9}$

\footnotetext{
${ }^{4}$ Bernard Williams, In the Beginning Was the Deed: Realism and Moralism in Political Argument (Princeton: Princeton University Press, 2005), p. 3.

${ }^{5}$ Vincent Chiao, Criminal Law in the Age of the Administrative State (Oxford and New York: Oxford University Press, 2019), p. 28.

${ }^{6}$ Ibid.

${ }^{7}$ Ristroph, n. 2 above. There is an earlier anticipation of this problem-albeit associated with the absence of a theory of the limits of criminalization, in Doug Husak's 1995 paper, "The Nature and Justifiability of Nonconsummate Offenses" where he writes of the danger of ending up in a position where "to question whether a social problem requires a solution within the criminal justice system is tantamount to denying that the social problem exists at all.' Douglas N. Husak, "The Nature and Justifiability of Nonconsummate Offences", in Douglas N. Husak (ed.), The Philosophy of Criminal Law: Selected Essays (Oxford and New York: Oxford University Press, 2010), 117, p. 118.

${ }^{8}$ Ristroph, n. 2 above.

${ }^{9}$ Ristroph (ibid.) identifies these as 'burdens exceptionalism', 'subject-matter exceptionalism', and 'operational exceptionalism'.
} 


\subsection{Burdens Exceptionalism}

The claim is that the criminal law imposes penalties ('hard treatment', sanctions, burdens...) that are harsher or in some other way more significant than those imposed by other forms of law. ${ }^{10}$ However, measured just by quantity this not plausible. It is true that, other than war, criminal law is 'the most dramatic instance of coercive state power familiar to us today, ${ }^{11}$ but the fact that some of its uses are indeed dramatic does not mean that all of them are, or that other areas of law should not (and, as it happens, do not) surpass criminal law in (quantitative) seriousness. Fines for regulative failings in pharmaceutical and environmental domains can dwarf those imposed by the criminal law.

Of course, that does not deal with other forms of punishment such as imprisonment, corporal punishments, and punishments designed to shame. Measuring and comparing these quantitatively is difficult. It is not obvious that, say, two weeks' imprisonment is more severe than a fine of $£ 1$ million, or what the answer is to Peter Moskos's provocative question, 'given the choice between five years in prison or ten brutal lashes, which would you choose?'. ${ }^{12}$ Moreover, compulsory detention is not unique to criminal law (consider, for example, the detention of those with mental health issues that render them a risk to themselves or others or of those with certain serious infectious diseases, and the partial detention of certain citizens under 'control orders' of various kinds). In short, the claim of burdens exceptionalism is weak, although I have so far not dealt with the message communicated by punishment, which is discussed below.

\subsection{The Seriousness/Nature of the Wrong}

A second possibility is that there is something special in the nature of the conduct regulated by the criminal law. For example, that the criminal law is (or ought to be) concerned with:

public wrongs... A public wrong... is a wrong that violates or threatens the civil order. ${ }^{13}$

punishment is justified where a citizen attacks another in ways that deny their civic equality and undermine our ability to maintain a common civic life. ${ }^{14}$

As a matter of the criminal law in practice-certainly in both the USA and England and Wales - this is far from the reality. The criminal law in those places deals

\footnotetext{
${ }_{10}$ Ristroph includes the claim that punishment is intended to be stigmatising under burdens exceptionalism, but for reasons that will become clear, I have included that feature in the discussion of the communicative function below.

11 Chiao, n. 5 above.

12 Peter Moskos, In Defense of Flogging (New York: Basic Books, 2011), p. 2.

13 Antony Duff, The Realm of Criminal Law (Oxford and New York: Oxford University Press, 2018), p. 183.

14 Ekow Yankah, “The Right to Reintegration”, New Criminal Law Review 23(1) (2020): 74, p. 75.
} 
in, and has always dealt in, conduct far wider than both definitions of public wrong given above.

Nevertheless, could it be that in its ideal form criminal law would exhibit subjectmatter exceptionality? We need to disentangle three variants of the claim: (i) Only the (ideal) criminal law deals with public wrongs; (ii) the (ideal) criminal law deals with all and only public wrongs; (iii) the (ideal) criminal law is distinctive in its perspective on the conduct that it criminalises: for it portrays that conduct ... as constituting a wrong that is "public". 15

(i) and (ii) could be established by definitional fiat; all public wrongs are only the business of the criminal law, and/or only and all those things with which the criminal law is concerned are public wrongs. However, such a definitional move would hardly prove the case for criminal law exceptionality. Moreover, it is implausible to think that the kinds of conduct with which the criminal law is concerned are uniquely the concern of the criminal law (as is clear, for example, when a victim sues his/her alleged attacker often following a failed public prosecution ${ }^{16}$ ). (iii) is more plausible - although of course far more would need to be said about what it is to constitute a wrong as public_-and leads neatly to the third candidate form of exceptionalism.

\subsection{Calling to Account/Censure and Condemnation}

Ristroph's 'operational exceptionalism' includes procedural and enforcement matters, but for reasons of space, I focus here only on the (alleged) communicative feature of the criminal law. Consider the following claims:

'...it is the distinctive feature of the penal law that it condemns offenders as wrongdoers, marshalling the formal censure of conviction and coercive sanctions on this ground". ${ }^{17}$

'Punishment is a conventional device for the expression of attitudes of resentment and indignation, and of judgments of disapproval and reprobation, on the part either of the punishing authority himself or of those "in whose name" the punishment is inflicted'. ${ }^{18}$

Punishment is 'a distinctive kind of practice, of imposing censure-expressing burdens on supposed offenders for their supposed offenses...' 19

\footnotetext{
15 Antony Duff and Sandra Marshall, this issue.

16 Famously, the American former footballer and film star, O J Simpson, lost a civil suit for the "wrongful deaths' of his former wife and her partner after he had been acquitted of their murder.

17 Herbert Wechsler, "Codification of Criminal Law in the United States: The Model Penal Code", Columbia Law Review 68(8) (1968): 1425, p. 1435.

18 Joel Feinberg, "The Expressive Function of Punishment", in Joel Feinberg (ed.), Doing \& Deserving: Essays in the theory of Responsibility (Princeton: Princeton University Press, 1970), 95, p. 98.

19 Antony Duff, Punishment, Communication, and Community (Oxford and New York: Oxford University Press, 2001), p. xv.
} 
'Punishment secures the condition of sufficient security, it communicates to the offender the wrongs that he has done to his victim and to the community, and it tries in so doing to reinforce in him his commitment to morality'. ${ }^{20}$

The claim here is that what is special about the (ideal) criminal law is that it represents fellow citizens holding the alleged offender to account for a wrong constituted as a public wrong (iii above). Moreover, if properly convicted, the conviction and punishment communicate a certain blaming or censuring message on behalf of his fellow citizens. Of course, this is not uncontroversial. Perhaps the most interesting critique comes from those who think that the criminal law should hold to account, but that it should do so without 'retributive blame'. There are (at least) two versions of this: for Lacey and Pickard, the criminal law should call to account and attribute responsibility (where appropriate), but in a therapeutic or clinical mode that eschews 'retributive' or 'affective' blame. ${ }^{21}$ For Pereboom, and some other moral responsibility sceptics, it should hold to account, but not in terms of 'basic desert'. ${ }^{22}$

The issue, it seems, revolves around the state's response to the defendant's (let us assume, inadequate) answer to being called to account. For Lacey and Pickard, and Pereboom, the response is essentially forward-looking. The state says in reply to the lack of a defence, 'you did this, and now we will help you come to terms with it and reform' or 'you did this, and now we need to protect ourselves from you'. The censure theorist says, 'you did this, and we censure you'. Yet, the censure theorist, too, is partly concerned with the future; 'you did this, and we censure you, and we do so in part to remind you of your commitment to living together with others on certain terms and to provide you with the vehicle for reconciliation'.

I think, and have argued, that the criminal law ought to have the function described above. ${ }^{23}$ Is this enough to ground a claim of practice exceptionality that explains and justifies theoretical exceptionalism? The answers are yes, and yes and no. An ideal criminal law acts on behalf of the community to hold to account an alleged offender for a public wrong. If the offender is properly found guilty, s/he is convicted, and that conviction has expressive content. In addition, a particular kind of burdensome response may be imposed as a mode of expression, or to serve

\footnotetext{
${ }^{20}$ Matt Matravers, Justice and Punishment: The Rationale of Coercion (Oxford and New York: Oxford University Press, 2000), p. 267.

${ }^{21}$ Nicola Lacey and Hanna Pickard, "To Blame or to Forgive? Reconciling Punishment and Forgiveness in Criminal Justice", Oxford Journal of Legal Studies 35(4) (2015): 665; Hanna Pickard, "Responsibility without Blame: Philosophical Reflections on Clinical Practice", in Bill Fulford, Martin Davies and others (eds.), The Oxford Handbook of Philosophy and Psychiatry (Oxford and New York: Oxford University Press, 2013), 1134.

${ }^{22}$ Derk Pereboom, "Free Will Skepticism and Criminal Punishment", in Thomas Nadelhoffer (ed.), The Future of Punishment (Oxford and New York: Oxford University Press, 2013), 49. Pereboom defends a 'self-defence', incapacitative, account of punishment.

${ }^{23}$ Matravers, n. 20 above.
} 
consequentialist goals such as deterrence, rehabilitation, and incapacitation. ${ }^{24}$ In this, the ideal criminal law performs a distinctive or special function.

In one sense, then, the fact that ideal criminal law and punishment does have distinctive features blunts the objection that theories of the justification of criminal law and punishment take a wrong turn in responding to criminal law exceptionality. However, this distinctiveness - or exceptionality — of criminal law and punishment provides no reasons to ground their justification in the vindication of rights or 'applied moral philosophy'. Indeed, the account I defended in 2000 is cited approvingly by Chiao as a precursor of his public law approach. If the 'applied moral philosophy' criticism has bite-and it might in certain $\operatorname{cases}^{25}$ - it is not because it is a necessary consequence of believing that there are distinctive values realised by an ideal system of criminal law and punishment.

Of course, the practices of criminal law and punishment fall far short of the ideal described above. Trials are sparse in an era of plea bargains and guilty pleas, and many punishments are handed down after cursory hearings that bear no relation to the ideal of a communicative dialogue between the state and the alleged offender. This raises difficult questions about the relation of theory and practice, but also provides space to discuss what I take to be the most significant worry of those bothered by exceptionalism: the criminal law's 'free pass'.

\section{Theory and Practice}

The sub-sections above very briefly canvassed some of the arguments for and against the claim that the criminal law is in some way exceptional or distinctive. In each case, the situation on the ground, so the speak, seems to undermine the argument for the criminal law's exceptionality. Actual criminal law and criminal justice systems do not impose quantitively distinct sanctions, do not deal only in public wrongs, and do not operate to facilitate dialogue and communication.

This 'gap' between theory and practice can lead to a frustrating impasse in which the empirical reality of criminal justice is used as evidence against ideal theories and to which the reply is inevitably that we could not say what is wrong with this reality without an ideal theory to distinguish wrong from right. I think there is a way forward both in the debate over 'distinctiveness' and in that over the relationship between theory and practice. It is to argue that criminal law is distinctively valuable in various ways, but that it is also in its institutional form an instrument of public policy to be evaluated relative to other policies in ways that are appropriate to such policies. That is, as noted above, part of the fear of those who oppose criminal law

\footnotetext{
${ }^{24}$ I am not convinced that the response has to include 'hard treatment' (which is another reason to be suspicious of the claims of 'burdens exceptionalism'). I think it is at least possible that conviction is sufficient for the expression of appropriate censure. If so, it is censure and not hard treatment that is distinctive. See Matt Matravers, "Punishment, Suffering and Justice", in Stephen Farrall and others (eds.), Justice and Penal Reform: Re-shaping the penal landscape (London: Routledge, 2016), 27.

25 Michael Moore, Placing Blame: A General Theory of the Criminal Law (Oxford and New York: Oxford University Press, 1997).
} 
exceptionalism seems to be that to admit that criminal law is in some way special is to give it some kind of policy 'free pass'. That worry is understandable. The claim to be 'doing justice' has a weight that is hard to associate with, for example, 'building roads'. Moreover, as Ristroph points out, criminal justice is more resistant than many other policies when it comes to aggregation; its outcomes seem to be the results of decisions made in individual cases-justice done (or not) in each instance-and so its systemic features are easy to miss. ${ }^{26}$

In addition, we know that the operations of the criminal law and criminal punishment-even in ideal form-will always be less than ideal. Given the harms inflicted by punishment, that is a serious worry. Inevitably, some innocent people will be punished; the nature of the current economic system means that punishment will fall disproportionately on those already disadvantaged and unlucky; punishments, once imposed, will have effects beyond what we intend both in terms of the impact on the offender and in terms of 'collateral' consequences. Given those harms, and that they are foreseeably imposed, the desire to constrain and corral the criminal law is also understandable.

However, there is no reason to conflate arguments in favour of a particular theory of a distinctive criminal law and claims that the criminal law so described is all things considered justified as a matter of public policy. Of course, the theory must pass muster in its own terms, but beyond that it must be turned from an inevitably abstract account of the criminal law into something appropriate for the here and now. And, even once that is done, its implementation must be subject to critical review in terms of what it might achieve and what it might cost both economically and in terms of other values.

Consider, as an analogy, state supervised compulsory public education of children. We can imagine a theory of such public education. It might include the fact that such a policy would have certain instrumental benefits: that it would equip children with some skills that enable them to go on to employment and to contribute the state's gross domestic product; that it would facilitate governance; and so on. It might also (plausibly) include some non-instrumental considerations such as the way a shared educational experience helps constitute a community. The point is that even if we were fully to endorse that theory and, ex hypothesi, regard it as justifying a distinctive practice of state supervised compulsory public education for children, there would still be a great deal of work to do. The theory would not tell us about the design of school buildings, the start and end times of a 'good' school day, the structure of the academic year, the potential costs to families of children not being accommodated with their friends when they move schools, and so on (and on and on).

Moreover, to achieve the goods desired, there may be other things that need to be in place that are not part of, but preconditions of, the success of public education as defined by the theory. The children attending school may need to be fed so as to counter poverty related hunger that distracts from learning and undermines the message of solidarity; those without a place to read quietly at home might need

${ }^{26}$ Ristroph, n. 2 above. 
before and after school care, and so on (and on and on). These are empirical matters, but they will shape any assessment, and implementation, of the theory of public education.

The same holds, I believe, for criminal law and criminal justice. In what the philosopher David Gauthier calls 'a post-anthropomorphic, post-theocentric, posttechnocratic world', ${ }^{27}$ there is very little that holds citizens together. Liberal democracy is a fragile achievement without foundations beyond the wills of the persons involved. ${ }^{28}$ In sustaining this, criminal law can play a distinct constitutive role in affirming the common good of the parties. ${ }^{29}$ However, it can do so only given certain conditions such as relative equality between the parties (including equality before the law). Thus, whether this account is appropriate for the here and now is something to be decided based on whether those conditions obtain 'on the ground'. If they do not, and if there are independent reasons to favour those conditions, then the task is one of 'transition'. If they do, then the implementation of criminal law as thus conceived still requires further work, since we need to know what policies and procedures will best promote the intrinsic goods at which it aims. Nothing in the claim that there are distinctive goods to be achieved in criminal justice gives it a 'free pass' to being all things considered justified. Indeed, as with education, if we are to achieve those distinctive goods, we will need first to attend to many of the inequalities that prohibit their realisation as well as to 'best practices' in implementation.

\section{Discussion}

There is something I agree with in all of the contributions to this issue. Unlike most, but in common with Antony Duff and Sandra Marshall, I believe it is possible to give a theoretical account of criminal justice and the criminal law that identifies distinctive values that it, and it alone, can achieve. I also agree with the point made by all contributors, but most forcefully by Francesco Viganò, that no existing instance of criminal law and justice comes close to instantiating that theoretical account.

Alice Ristroph objects to a too quick elision of distinctive and exceptional. The latter, she argues, 'requires a concept of the norm.' That is, it

Requires us to identify some category or group, specify the normal properties of that group, and then identify one member of the group that does not share one or more of those normal properties even as it remains properly classified as a member of the larger group. ${ }^{30}$

And, for Ristroph, the relevant group is 'law'.

${ }^{27}$ David Gauthier, "Moral Artifice", Canadian Journal of Philosophy 18(2) (1988): 385, p. 385.

${ }^{28}$ John Charvet, Liberalism: the basics (London: Routledge, 2018); John Charvet, The Nature and Limits of Human Equality (London: Palgrave Macmillan, 2013).

${ }^{29}$ Matravers, n. 20 above.

${ }^{30}$ Alice Ristroph, this issue. 
As I have again invoked 'distinctiveness' above, it is worth saying something about this even though I am still not entirely sure of the distinction. It seems to me possible to say the following. Like many (all?) of the contributors, I think criminal justice is a social construct designed to achieve human ends. In this way it is, as Rocío Lorca writes, '...one more means of Government'. ${ }^{31}$ Pace Ristroph, then, for me the most important comparator is not 'law', but other public institutional practices designed to further the interests of society and its members (hence my insistence that criminal law is not given what I call above 'a free pass'). However, criminal justice, criminal law, and punishment are not, as Lorca puts it, 'just one more means...' (italics mine). Other forms of public policy share many of their ends, but (at least as I conceptualise it) criminal justice secures the condition of sufficient security, communicates to the offender the wrongs that s/he has done to both the victim and the community, and tries to do so in ways that reinforce in the offender his/her commitment to the regime of social co-operation. ${ }^{32}$ The communicative and censuring aspects, designed to reinforce the contingent agreement underpinning social co-operation, are essential to the theory, distinctive, and (I tentatively think) exceptional in the sense of differing from the theoretical accounts of other 'normal' public institutional practices.

Having said that, there are three serious caveats. First, the theoretical account sketched above operates at a very high level of abstraction. Thus, and to agree with a point made by Duff and Marshall, it does not in itself tell us how to organise policing, the criminal process, or even punishment. These are vital empirical matters, but they are not just empirical. To know whether, say, such-and-such a police policy is a good one, one needs to know the ends at which the policy aims and the constraints that govern it. Any adequate theory will thus combine what Brian Barry called 'the a priori' and 'the empirical' stages of enquiry. ${ }^{33}$

Second, I agree entirely with both Christoph Burchard and Alice Ristroph that there are very significant dangers in the claim of exceptionalism (and, I would add, in remaining in the realm of a priori theorising). Burchard is undoubtedly right that the ways in which criminal law theorists have protected-dare I say, 'policed'- the boundaries of the subject have led both to ideological thoughtlessness and complacency, and to insufficient attention being paid to the 'dark sides' of criminal law in action. ${ }^{34} \mathrm{I}$ am less clear about the causal relations claimed by Ristroph-and, as she says, to what degree some of the issues she identifies are peculiar to the US legal academy - but I agree with her about the dangers she discusses and the need for criminal law theory to be much more open to other disciplines (I could hardly do otherwise given my commitment to an empirical dimension as part of theorising the phenomenon). However, I side with the Ristroph who holds that criminal

\footnotetext{
31 Rocío Lorca, this issue.

32 Matravers, n. 20 above, p. 267.

33 Brian Barry, Theories of Justice: A Treatise on Social Justice (1) (London: Harvester Wheatsheaf, 1989), p. 345.

34 Christoph Burchard, this issue.
} 
law exceptionalism can lead to certain bad outcomes rather than the Ristroph who claims that it must do so. ${ }^{35}$

Third, I think we need to pay more attention to the issue raised by Duff and Marshall: that the constitutive value of the practice makes it "worth preserving if, and only if, the kind of polity that it constitutes... is one that we would find normatively attractive'. ${ }^{36}$ 'Liberal' or 'classical' criminal law theory fits into a liberal (in the broadest sense) picture of political philosophy. We should not be certain, or complacent, about whether there are no more compelling wholesale alternatives.

Where does this leave us? Certainly, it should lead us-as criminal law theorists - to be more acutely aware of our own assumptions, more cautious in our theorising, and more aware of how our thoughts might 'translate' into the real world. Perhaps more importantly, I think it should also make us less certain that the framework in which we work is always the best for understanding actual legal practices, particularly those that demonstrate egregious disregard for the values embedded in that framework.

Consider an analogy. In both the USA and the UK, right-wing governments are currently engaged in legislating around procedural matters when it comes to voting. They are doing so in the name of 'electoral integrity' and 'protecting democracy'. Is this best understood, and explained, uniquely in the language of democratic theory? The answer seems to me to be no. It is, at least in large part, an exercise of power by those who have it to try to ensure that they keep it. Similarly, I do not think that criminal law theory is always best placed to 'understand actual legal practices', as Ristroph puts it. ${ }^{37}$ When it comes to many aspects of those practices-in the USA and UK - they may be best explained by race, class, power, and politics.

Does that mean that criminal law theory is irrelevant, or an 'academic' exercise in the pejorative sense in which that word is sometimes used? The answer is no for two reasons; one familiar, one perhaps less so. The first is that to appreciate why, say, a sentence imposed on a teenager of life without the possibility of parole is not an instance, but a corruption, of the proper values of a criminal justice system, one needs to know what those values are and how they are best realised. Second, I think it is worth reminding ourselves of Michel Foucault's warning that not 'everything is bad, but... everything is dangerous, which is not exactly the same as bad. If everything is dangerous, then we always have something to do., 38

The history of both the theory and practice of criminal justice lends credence to Foucault's claim. Just to look at the twentieth century: the advocates of 'doing justice' in the mid-1970s believed themselves to be correcting the grave wrong of indeterminate sentences just as those who had introduced those sentences earlier

\footnotetext{
35 See, for example, the paragraph at the end of $\S 1$ of Ristroph's contribution that seems undecided between 'difficulty' and 'impossibility'.

36 Duff and Marshall, this issue.

37 Ristroph, this issue.

38 Afterword by Michel Foucault, "On the Genealogy of Ethics: An Overview of Work in Progress", in Hubert L. Dreyfus and Paul Rabinow, Michel Foucault: Beyond Structuralism and Hermeneutics, (Chicago: University of Chicago Press, 2nd ed. 1983).
} 
in the century believed themselves to be responding to the barbarism of retributivism. ${ }^{39}$ Human practices, like human beings, are flawed. With respect to the subject at hand, responding to those flaws requires criminal law theory, but not only that, and in addition, it requires a healthy scepticism when it comes to the promises of alternatives.

Acknowledgements I am grateful to all colleagues in 'The Political Turn(s) in Criminal Law Theory' workshop for discussion of this paper, to Christoph Burchard and Antony Duff for written comments, and to Nicola Recchia for editorial assistance.

Open Access This article is licensed under a Creative Commons Attribution 4.0 International License, which permits use, sharing, adaptation, distribution and reproduction in any medium or format, as long as you give appropriate credit to the original author(s) and the source, provide a link to the Creative Commons licence, and indicate if changes were made. The images or other third party material in this article are included in the article's Creative Commons licence, unless indicated otherwise in a credit line to the material. If material is not included in the article's Creative Commons licence and your intended use is not permitted by statutory regulation or exceeds the permitted use, you will need to obtain permission directly from the copyright holder. To view a copy of this licence, visit http://creativecommons.org/licen ses/by/4.0/.

Publisher's Note Springer Nature remains neutral with regard to jurisdictional claims in published maps and institutional affiliations.

\footnotetext{
${ }^{39}$ For discussion, see Matt Matravers, "Is Twenty-First Century Punishment Post-Desert?", in Michael Tonry (ed.), Retributivism Has a Past: Has it a Future? (Oxford and New York: Oxford University Press, 2011), 30 .
} 